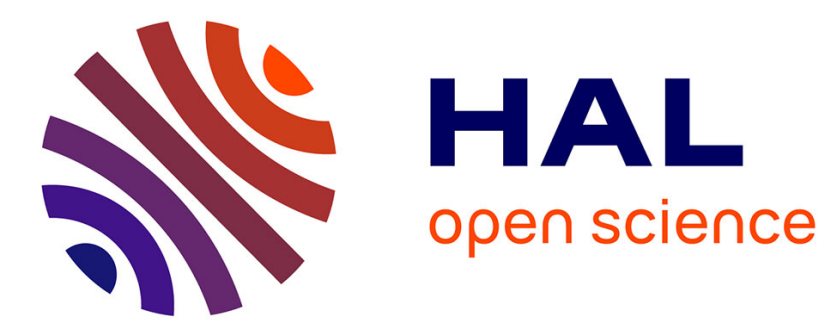

\title{
Efficient two-step access to azafluorenones and related compounds
}

Nada Marquise, Philip J. Harford, Floris Chevallier, Thierry Roisnel, Andrew

E. H. Wheatley, Philippe C. Gros, Florence Mongin

\section{- To cite this version:}

Nada Marquise, Philip J. Harford, Floris Chevallier, Thierry Roisnel, Andrew E. H. Wheatley, et al.. Efficient two-step access to azafluorenones and related compounds. Tetrahedron Letters, 2013, 54 (24), pp.3154-3157. 10.1016/j.tetlet.2013.04.020 . hal-00871003

\section{HAL Id: hal-00871003 https://hal.science/hal-00871003}

Submitted on 11 Oct 2013

HAL is a multi-disciplinary open access archive for the deposit and dissemination of scientific research documents, whether they are published or not. The documents may come from teaching and research institutions in France or abroad, or from public or private research centers.
L'archive ouverte pluridisciplinaire HAL, est destinée au dépôt et à la diffusion de documents scientifiques de niveau recherche, publiés ou non, émanant des établissements d'enseignement et de recherche français ou étrangers, des laboratoires publics ou privés. 


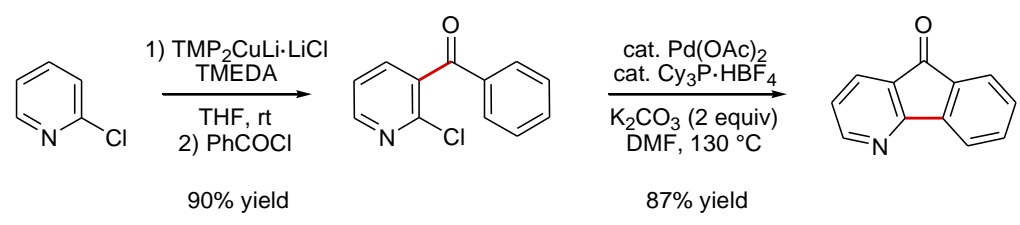

\title{
Efficient two-step access to azafluorenones and related compounds
}

\author{
Nada Marquise $^{\mathrm{a}}$, Philip J. Harford ${ }^{\mathrm{b}}$, Floris Chevallier ${ }^{\mathrm{a}}$, Thierry Roisnel ${ }^{\mathrm{c}}$, Andrew E. H. \\ Wheatley $^{\mathrm{b}, *}$, Philippe C. Gros ${ }^{\mathrm{d}}$, Florence Mongin ${ }^{\mathrm{a}, *}$ \\ ${ }^{a}$ Chimie et Photonique Moléculaires, UMR 6226 Institut des Sciences Chimiques de Rennes, CNRS-Université de Rennes 1, Bâtiment 10A, \\ Case 1003, Campus Scientifique de Beaulieu, 35042 Rennes, France \\ ${ }^{b}$ Department of Chemistry, University of Cambridge, Lensfield Road, Cambridge, CB2 1EW, UK \\ ${ }^{c}$ Centre de Diffractométrie X, UMR 6226 Institut des Sciences Chimiques de Rennes, CNRS-Université de Rennes 1, Bâtiment 10B, Campus \\ Scientifique de Beaulieu, 35042 Rennes, France \\ ${ }^{d}$ HECRIN, SRSMC, Université de Lorraine-CNRS, Boulevard des Aiguillettes, 54506 Vandouvre-Lès-Nancy, France
}

* Corresponding authors. E-mails: aehw2@cam.ac.uk, florence.mongin@univ-rennes1.fr

Keywords: Deprotometallation; Copper; Lithium; Heterocycle; Palladium

\begin{abstract}
:
Crystals of a lithiocuprate prepared from copper(I) chloride and lithium 2,2,6,6-tetramethylpiperidide (2 equiv) were isolated and analysed by X-ray diffraction as $(\mathrm{TMP})_{2} \mathrm{Cu}(\mathrm{Cl}) \mathrm{Li}_{2} \cdot \mathrm{THF}$. The observation of this species is consistent with its having a role in deprotocupration-aroylation for a higher-order bis(amido)cuprate. Phenyl pyridyl ketones, phenyl quinolyl ketones and phenyl thienyl ketones were prepared in tetrahydrofuran by this sequence using the lithiocuprate and aroyl chorides as electrophiles. Diaryl ketones bearing a chloro group at the 2 position (of a pyridyl or phenyl group) thus synthesized were next converted through palladium-catalysed ring closure to polycycles of the $5 H$-indeno[1,2-b]pyridin-5-one, $11 H$-indeno[1,2-b]quinolin-11-one, $9 H$ indeno $[2,1-c]$ pyridin-9-one and $8 H$-indeno[2,1-b]thiophen-8-one families.
\end{abstract}

\section{Introduction}

Azafluorenones represent the heterocyclic cores of many molecules of biological interest; derivatives have, for example, been described for their antifungal, ${ }^{1}$ antibacterial, ${ }^{2}$ and antimalarial ${ }^{3}$ properties.

In the course of the development of lithium-metal amido-based heterometallic bases, synergic reagents with which to functionalize aromatic compounds unsuitable for reaction with traditional organolithium bases have been identified and developed. ${ }^{4}$ Amongst these, the cuprate base prepared in situ from $\mathrm{CuCl}$ and 2 equiv of LiTMP (TMP $=2,2,6,6$ tetramethylpiperido), in addition to achieving regioselective deprotonation, gave metallated derivatives capable of reacting in situ with aroyl chlorides to afford the corresponding ketones. ${ }^{5}$ We realized that this approach, applied to the synthesis of 2-chloro diaryl ketones, could be combined with transition metal-catalysed cyclization to afford a straightforward method by which to synthesize azafluorenones and related compounds. In addition, whereas coupling involving $\mathrm{C}-\mathrm{H}$ bond activation has been the subject of numerous investigations, ${ }^{6}$ to our knowledge only one study has been devoted to azafluorenone synthesis, this using 2-bromo diaryl ketone reagents, ${ }^{7}$ which are more expensive than the corresponding chloro analogues.

\section{Results and discussion}

Recently, in order to gain more information about the lithiocuprate base, we attempted its crystallization. In the present case, the treatment of LiTMP with $\mathrm{CuCl}$ in toluene/THF followed by concentration and recrystallization from toluene at $-20{ }^{\circ} \mathrm{C}$ afforded colourless crystals which X-ray diffraction showed to be (TMP) ${ }_{2} \mathrm{Cu}(\mathrm{Cl}) \mathrm{Li}_{2} \cdot \mathrm{THF} \mathbf{1}$ (Figure $1) .^{8} \mathrm{~A}$ dimer is revealed in the solid state based on a $(\mathrm{LiCl})_{2}$ core with the halide ions remote from copper. The structure is closely related to the dimers of $(\mathrm{TMP})_{2} \mathrm{Cu}(\mathrm{CN}) \mathrm{Li}_{2} \cdot \mathrm{THF}^{9}$ and $(\mathrm{TMP})_{2} \mathrm{Cu}(\mathrm{I}) \mathrm{Li}_{2} \cdot \mathrm{THF},{ }^{10}$ with $\mathrm{Cu}$ maintaining a near linear geometry $\left(\mathrm{N}(1)-\mathrm{Cu}(1)-\mathrm{N}(2) 174.45(11)^{\circ}\right)$ and the amides acting as inter-metal bridges $(\mathrm{Cu}(1)-\mathrm{N}(1)-$ $\mathrm{Li}(1)$ 92.1(2), $\left.\mathrm{Cu}(1)-\mathrm{N}(2)-\mathrm{Li}(2) 84.77(19)^{\circ}\right)$. However, in contrast to the cyanide- and iodide-based dimers, in which the THF-solvated $\mathrm{Li}^{+}$ions reside within \pm 0.14 and $\pm 0.15 \AA$, respectively, of planes defined by the $(\mathrm{LiX})_{2}(\mathrm{X}=\mathrm{N}, \mathrm{I})$ metallocyclic cores of the structures, in $\mathbf{1}_{2}$ they are significantly displaced (by $\pm 0.49 \AA$ ) from the analogous $(\mathrm{LiCl})_{2}$ core plane. Lastly, we can empirically view formation of the higher-order dimer as resulting from the formal insertion of two units of in situ-generated $\mathrm{LiCl} \cdot \mathrm{THF}^{11}$ into a lower-order dimer based on a (NCuNLi $)_{2}$ ring. ${ }^{10}$

Whereas early synthetic work with these systems presumed the use of higher-order cuprates such as $(\mathrm{TMP})_{2} \mathrm{Cu}(\mathrm{CN}) \mathrm{Li}_{2}$ as deprotocuprating agents, ${ }^{9}$ this cuprate structure-type has been established to be in competition ${ }^{10-}$ 
${ }^{11}$ with lower-order (TMP) $)_{2} \mathrm{CuLi}$ and both higher- and lower-order lithiocuprates have proved capable of being isolated from similar media. ${ }^{10}$ Moreover, the conditions employed here - 2:1 combination of lithium amide with $\mathrm{CuCl}$ in THF/TMEDA - favour retention in solution of in situ-formed $\mathrm{LiCl}^{12}$ Combined with recent synthetic results concerning the metallation of halopyridines ${ }^{5 \mathrm{c}}$ and the theoretical modelling of cuprate bases, ${ }^{10}$ these data suggest that efficient deprotocupration-aroylation requires only the presence of components consistent with the formulation of a higher-order bis(amido)cuprate. Indeed, spectroscopic studies on $\mathbf{1}$ show the presence in both benzene and THF solutions of the higher-order cuprate alongside a small but detectable amount of another species. ${ }^{8}$ Based on recent studies that reported the characterization of $\mathrm{TMP}_{2} \mathrm{CuLi}$ it is possible to attribute the minor signals to the in situ formation of this lower-order cuprate. ${ }^{10}$

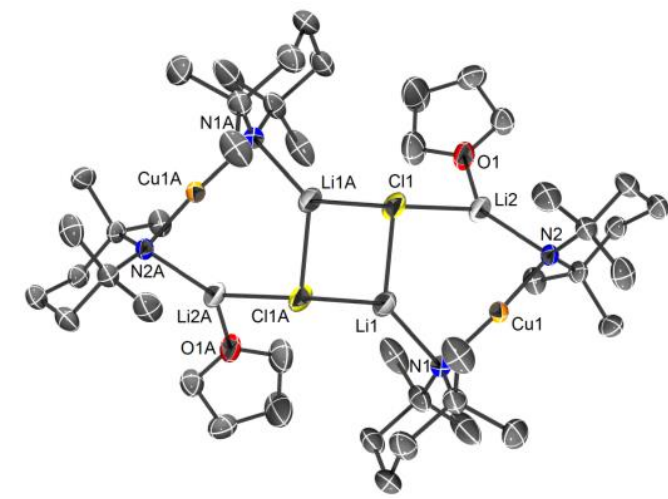

Figure 1. ORTEP diagram (50\% probability) of the dimer of lithiocuprate $\mathbf{1}$ with $\mathrm{H}$-atoms omitted. ${ }^{13}$

Table 1. Synthesis of 2, 3a-c, 4, 5 and $\mathbf{6}$ by deprotocupration followed by aroylation (TMEDA = $N, N, N^{\prime}, N^{\prime}-$ tetramethylethylene-diamine).

$$
\mathrm{Ar}-\mathrm{H} \underset{\mathrm{THF}, \mathrm{rt}, 2 \mathrm{~h}}{\stackrel{\text { 1) }(\mathrm{TMP})_{2} \mathrm{CuLi} \cdot \mathrm{LiCl} \text { (1 equiv) } \mathrm{CIC}(\mathrm{O}) \mathrm{Ar}^{\prime}}{\longrightarrow}} \mathrm{Ar} \longrightarrow \mathrm{Ar}^{\prime}
$$

Entry

${ }^{\mathrm{a}}$ Trapping step performed at rt.

${ }^{\mathrm{b}}$ Trapping step performed at $60{ }^{\circ} \mathrm{C}$.

Our deprotocupration-aroylation method was next applied to the synthesis of 3-benzoyl-2-chloroquinoline and -2chloropyridine 2 and 3a (44 and 90\% yield, respectively), ${ }^{5}$ compounds for which subsequent cyclization could lead to heterocyclic tricycles (Table 1, entries 1,2). We also chose the diaryl ketones $3 \mathbf{b}-\mathbf{c},{ }^{14} \mathbf{4}^{15}{ }^{15} \mathbf{5}^{16}$ and $\mathbf{6}^{17}$ as other potential candidates to evaluate the combination of deprotocupration-aroylation with transition metal-catalysed cyclization, and prepared them by extending the method (Table 1, entries 3-7). In particular, we discovered that the trapping step usually performed at room temperature can be improved in the thiophene series by raising the temperature to $60{ }^{\circ} \mathrm{C}$ (Table 1, entries 6,7).

We next turned to the synthesis of azafluorenones and related compounds. Owing to their presence in natural products and compounds of medicinal interest, the synthesis of fluorenones has received significant attention. ${ }^{18}$ With the aim of developing a short access method to such compounds, here we have targeted a route involving cyclization of the ketones 2-6. 
4-Azafluorenone (7) was previously synthesized by several groups, ${ }^{19}$ and sometimes under harsh conditions. For example, Stauffer and co-workers prepared the tricycle by heating 2-phenylnicotinic acid at $190{ }^{\circ} \mathrm{C}$ in polyphosphoric acid, 2-phenylnicotinic acid being prepared in two steps from 2-chloro-3-cyanopyridine. ${ }^{20}$ The cyclization of 2-chloro3-benzoylpyridine (3a) to 4-aza-fluorenone $(7)^{21}$ was first optimized. Inspired by a previously described cyclization of 2-chloro diaryl aniline to carbazole,$^{22}$ the reactions were attempted in the presence of catalytic amounts of $\mathrm{Pd}(\mathrm{OAc})_{2}$ and electron-rich bulky trialkyl phosphine, and used $\mathrm{K}_{2} \mathrm{CO}_{3}$ as a base. Using $\mathrm{Cy}_{3} \mathrm{P}$ in DMF at $130{ }^{\circ} \mathrm{C}$, different transition metal-ligand ratios were tested. The best result was observed using $5 \mathrm{~mol} \%$ of $\mathrm{Pd}(\mathrm{OAc})_{2}$ and $10 \mathrm{~mol} \%$ of phosphine; using $20 \mathrm{~mol} \%$ of $\mathrm{Pd}(\mathrm{OAc})_{2}$ and $10 \mathrm{~mol} \%$ of phosphine, a lower yield was observed due to recovered starting material (Scheme 1).<smiles>O=C(c1ccccc1)c1cccnc1Cl</smiles>

3a

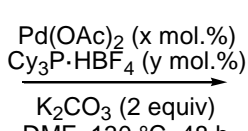
$\mathrm{DMF}, 130^{\circ} \mathrm{C}, 48 \mathrm{~h}$

$x=5 ; y=10: 87 \%$ yield

$x=5 ; y=15: 82 \%$ yield

$\mathrm{x}=10 ; \mathrm{y}=10: 81 \%$ yield

$x=20 ; y=10: 64 \%$ yield

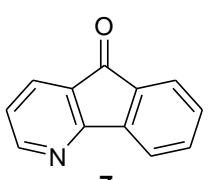

7

Scheme 1. Optimization of the $\mathrm{Pd}(\mathrm{OAc})_{2}-\mathrm{Cy}_{3} \mathrm{P}$ ratio for the cyclization affording $5 H$-indeno[1,2-b]pyridin-5-one (or 4azafluorenone, 7).

Under the best reaction conditions identified in Scheme $1,^{23} 11 H$-indeno[1,2-b]quinolin-11-one $(\mathbf{8})^{24}$ and 8 methoxy-5H-indeno[1,2-b]pyridin-5-one $(\mathbf{9})^{25}$ were formed from the ketones $\mathbf{2}$ and $\mathbf{3 b}$ respectively, and isolated in 63 $69 \%$ yield (Scheme 2). The ketone 3c, expected to allow further coupling thanks to an additional chloro group, did not afford the expected chloro cyclized product; bare $5 H$-indeno[1,2- $b$ ]pyridin-5-one (7) was the sole product identified using $\mathrm{Cy}_{3} \mathrm{P}$ or ${ }^{t} \mathrm{Bu}_{3} \mathrm{P}$.<smiles>O=C(c1ccccc1)c1cc2ccccc2nc1Cl</smiles>

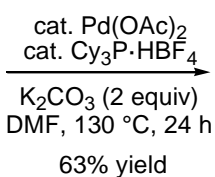<smiles>O=C1c2ccccc2-c2nc3ccccc3cc21</smiles><smiles>COc1ccc(C(=O)c2cccnc2Cl)cc1</smiles>

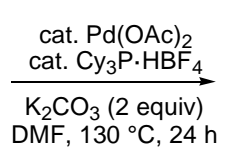<smiles>COc1ccc2c(c1)-c1ncccc1C2=O</smiles>

Scheme 2. Cyclization of $\mathbf{2}$ and $\mathbf{3 b}$ giving $11 H$-indeno[1,2-b]quinolin-11-one (8) and 8-methoxy-5H-indeno[1,2-b]pyridin-5one (9).

Starting from the diaryl ketone $\mathbf{4}$, in which the 2-chloro group is connected to the phenyl component, the cyclization proved more difficult. Recourse to a tetraalkylammonium chloride, as recommended by Kraus and Kempema for the cyclization of bromo diaryl ketones, ${ }^{7}$ led to the expected methoxy-substituted $9 H$-indeno[2,1-c]pyridin-9-one $\mathbf{1 0}^{26}$ in $48 \%$ yield. Using ${ }^{t} \mathrm{Bu}_{3} \mathrm{P}$ in this case did not give the same result and led to the cyclized demethylated aza-xanthone $\mathbf{1 1}^{27}$ and the non-cyclized dechlorinated product $\mathbf{1 2},{ }^{5 \mathrm{~b}}$ both of which were isolated in low yields (Scheme 3 ).

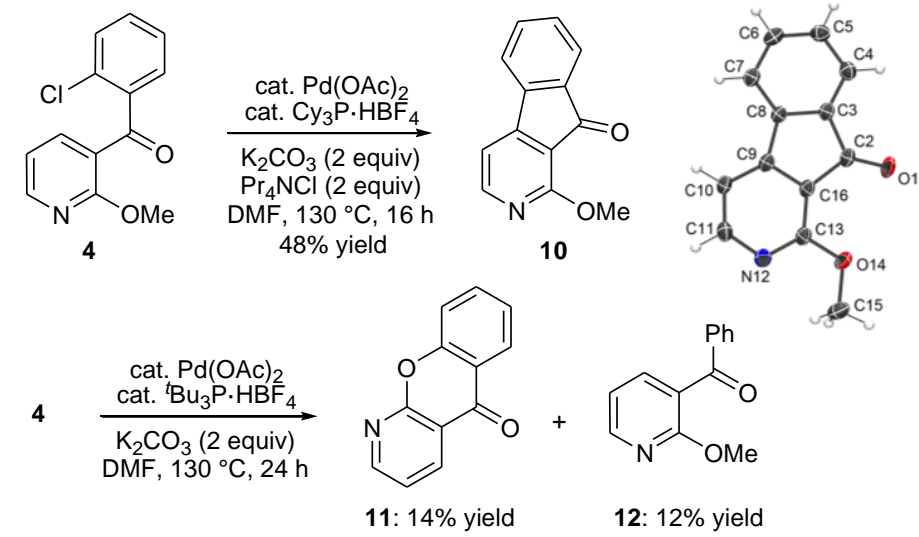

Scheme 3. Synthesis and ORTEP diagram (50\% probability) of 1-methoxy-9H-indeno[2,1-c]pyridin-9-one (10) 


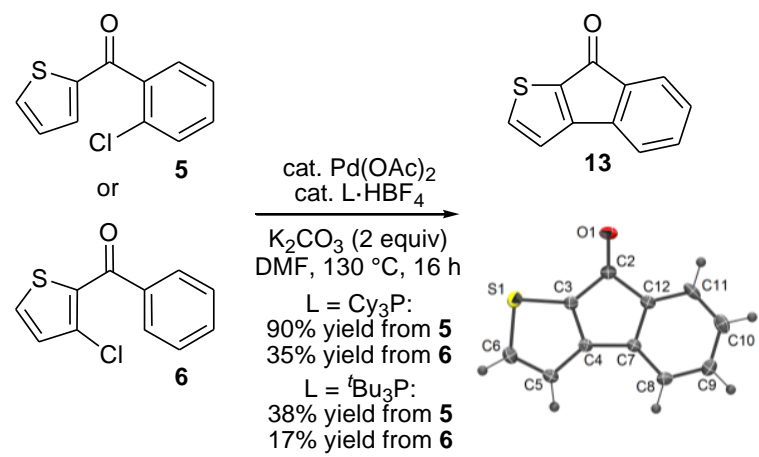

Scheme 4. Synthesis and ORTEP diagram (50\% probability) of $8 H$-indeno[2,1- $b]$ thiophen- 8 -one (13).

8H-Indeno[2,1-b]thiophen-8-one (13) was efficiently synthesized by Campo and Larock from 3-(2-bromophenyl)thiophene using palladium-catalysed cyclocarbonylation. ${ }^{28}$ Starting from $\mathbf{5}$, which bears the chloro group on the phenyl ring, both $\mathrm{Cy}_{3} \mathrm{P}$ and ${ }^{t} \mathrm{Bu}_{3} \mathrm{P}$ were tested as ligand in DMF at $130{ }^{\circ} \mathrm{C}$, affording $13^{29}$ in 90 and $38 \%$ yield, respectively. Lower 35 and $17 \%$ yields were respectively obtained from $\mathbf{6}$, for which the chloro group is present on the thiophene ring (Scheme 4).

\section{Conclusion}

In summary, different heterocyclic diaryl ketones were synthesized by deprotocupration-aroylation using a lithiocuprate which crystallised as (TMP $)_{2} \mathrm{Cu}(\mathrm{Cl}) \mathrm{Li}_{2}$. THF. The diaryl ketones bearing a halogen at the 2 position of one of the aryl groups, their cyclization under palladium catalysis was considered. $\mathrm{Cy}_{3} \mathrm{P}$ was identified as a more suitable ligand than ${ }^{t} \mathrm{Bu}_{3} \mathrm{P}$ for performing the reactions. Except when a second halogen was present on the 2-chloro diaryl ketone, azafluorenones and related compounds (including quinolyl or thienyl moieties instead of pyridyl) were isolated in medium to high yields.

\section{Acknowledgments}

The authors gratefully acknowledge the financial support of the Agence Nationale de la Recherche (ACTIVATE program) (to N.M. and P.H.), the Institut Universitaire de France (to F.M.), Rennes Métropole (to F.M.) and the UK EPSRC (to P.H.).

\section{References and notes}

$1 \quad$ Wu, Y. C. Heterocycles 1989, 29, 463-475.

2 Prachayasittikul, S.; Manam, P.; Chinworrungsee, M.; Isarankura-Na-Ayudhya, C.; Ruchirawat, S.; Prachayasittikul, V. Molecules 2009, 14, 4414-4424.

3 Mueller, D.; Davis, R. A.; Duffy, S.; Avery, V. M.; Camp, D.; Quinn, R. J. J. Nat. Prod. 2009, 72, 1538-1540.

4 (a) Mulvey, R. E.; Mongin, F.; Uchiyama, M.; Kondo, Y. Angew. Chem. Int. Ed. 2007, 46, 3802-3824; (b) Mulvey, R. E. Acc. Chem. Res. 2009, 42, 743-755; (c) Haag, B.; Mosrin, M.; Ila, H.; Malakhov, V.; Knochel, P. Angew. Chem. Int. Ed. 2011, 50, 9794-9824; (d) Mongin, F.; Uchiyama, M. Curr. Org. Chem. 2011, 15, 2340-2361.

5 (a) Nguyen, T. T.; Chevallier, F.; Jouikov, V.; Mongin, F. Tetrahedron Lett. 2009, 50, 6787-6790; (b) Nguyen, T. T.; Marquise, N.; Chevallier, F.; Mongin, F. Chem. Eur. J. 2011, 17, 10405-10416; (c) Snégaroff, K.; Nguyen, T. T.; Marquise, N.; Halauko, Y. S.; Harford, P. J.; Roisnel, T.; Matulis, V. E.; Ivashkevich, O. A.; Chevallier, F.; Wheatley, A. E. H.; Gros, P. C.; Mongin, F. Chem. Eur. J. 2011, 17, 13284-13297.

6 (a) Campeau, L.-C.; Parisien, M.; Jean, A.; Fagnou, K. J. Am. Chem. Soc. 2006, 128, 581-590; (b) Alberico, D.; Scott, M. E.; Lautens, M. Chem. Rev. 2007, 107, 174-238.

7 Kraus, G. A.; Kempema, A. J. Nat. Prod. 2010, 73, 1967-1968.

8 Compound 1: mp 173-175 ${ }^{\circ} \mathrm{C}$; elemental analysis calcd (\%) for $\mathrm{C}_{44} \mathrm{H}_{88} \mathrm{Cu}_{2} \mathrm{Li}_{4} \mathrm{~N}_{4} \mathrm{O}_{2} \mathrm{Cl}_{2}$ : C 56.77, $\mathrm{H}$ 9.53, $\mathrm{N}$ 6.02, $\mathrm{Cl}$ 7.62; found: C 56.34, H 9.69, N 6.03, $\mathrm{Cl} 7.92 ;{ }^{1} \mathrm{H}$ NMR $\left(500 \mathrm{MHz}, 298 \mathrm{~K}, \mathrm{C}_{6} \mathrm{D}_{6}\right)$ : $\delta 3.71$ (br, m, 4H; THF), 2.09 (br, m, 2H; TMP-3,5), 1.84 (s, 6H; TMP-Me), 1.71-1.68 (m, 18H; TMP-Me), 1.50 (br, m, 6H; TMP-3,5), 1.43 (br, m, 4H; THF), 1.18 ppm (m, 4H; TMP-4); ${ }^{13} \mathrm{C}$ NMR (125 MHz, 298K, $\mathrm{C}_{6} \mathrm{D}_{6}, G=$ lower-order or Gilman-type cuprate $\mathrm{TMP}_{2} \mathrm{CuLi}, L=$ higher-order or Lipshutz-type cuprate 1): $\delta 68.7$ (THF), 54.6 (TMP-2, G), 54.0 (TMP-2, L), 52.1 (TMP-2, L), 42.6 (TMP-3,5 G), 42.4 (TMP-3,5 L), 41.1 (TMP-3,5 L), 40.6 (TMP-Me, $G$ ), 39.0 (TMP-Me $L$ ), 38.6 (TMP-Me, $L$ ), 35.0 (TMP-Me, $G$ ), 34.6 (TMP-Me, $L$ ), 32.0 (TMP-Me, $L$ ), 25.3 (THF), 20.6 (TMP-4, L), 19.8 (TMP-4, L), 19.7 ppm (TMP-4, G); ${ }^{7} \mathrm{Li}$ NMR spectroscopy $\left(194 \mathrm{MHz}, 298 \mathrm{~K}, \mathrm{C}_{6} \mathrm{D}_{6}, G=\mathrm{TMP}_{2} \mathrm{CuLi}, L=\right.$ 1): $\delta 1.9$ (s, 6Li, L), 1.3 ppm (s, Li, G); ${ }^{1} \mathrm{H}$ NMR (500 MHz, 298K, d $\mathrm{d}_{8}$ THF): 3.65 (br, m, 4H; THF), 1.81 (br, m, 4H; THF), 1.68 (br, m, 4H; TMP-4), 1.38, 1.09 (s, 24H, TMP-Me), 1.33 ppm (br, m, 8H, TMP-3,5); ${ }^{1} \mathrm{H}$ NMR (500 MHz, $273 \mathrm{~K}, \mathrm{~d}_{8}$-THF): $\delta 3.65$ (br, m, 4H; THF), 1.81 (br, m, 4H; THF), 1.67 (br, m, 4H; TMP-4), 1.34, 1.08 (s, 24H, TMP-Me), 1.31 ppm (br, m, 8H, TMP$3,5) ;{ }^{13} \mathrm{C}$ NMR $\left(125 \mathrm{MHz}, 298 \mathrm{~K}, \mathrm{~d}_{8}\right.$-THF, $\left.G=\mathrm{TMP}_{2} \mathrm{CuLi}, L=\mathbf{1}\right): \delta 68.2$ (THF), 54.2 (TMP-2 L), 50.0 (TMP-2 G), 41.9 (TMP3,5 L), 38.6 (TMP-3,5 G), 37.3 (br, m, TMP-Me, $L$ ), 32.2, 32.1 (TMP-Me G), 26.4 (THF), 20.5 (TMP-4 L), 19.3 ppm (TMP-4, $G) ;{ }^{13} \mathrm{C}$ NMR $\left(125 \mathrm{MHz}, 273 \mathrm{~K}, \mathrm{~d}_{8}\right.$-THF, $G=\mathrm{TMP}_{2} \mathrm{CuLi}, L=1$ ): $\delta 65.1$ (THF), 51.3 (TMP-2 L), 47.1 (TMP-2 G), 39.1 (TMP-3,5 L), 35.7 (TMP-3,5 G), 34.8 (br, m, TMP-Me, L), 29.4, 29.3 (TMP-Me G), 23.0 (THF), 18.0 (TMP-4 L), 17.5 ppm (TMP-4, G); ${ }^{7} \mathrm{Li}$ NMR spectroscopy (194 MHz, 298K, d $\mathrm{d}_{8}$ THF): $\delta 0.7 \mathrm{ppm}(\mathrm{s}) ;{ }^{7} \mathrm{Li}$ NMR spectroscopy $\left(194 \mathrm{MHz}, 273 \mathrm{~K}, \mathrm{~d}_{8}-\mathrm{THF}\right): \delta 0.2 \mathrm{ppm}$ (s). 
9 Usui, S.; Hashimoto, Y.; Morey, J. V.; Wheatley, A. E. H.; Uchiyama, M. J. Am. Chem. Soc. 2007, 129, 15102-15103.

10 Komagawa, S.; Usui, S.; Haywood, J.; Harford, P. J.; Wheatley, A. E. H.; Matsumoto, Y.; Hirano, K.; Takita, R.; Uchiyama, M. Angew. Chem. Int. Ed. 2012, 51, 12081-12085.

11 Haywood, J.; Morey, J. V.; Wheatley, A. E. H.; Liu, C.-Y.; Yasuike, S.; Kurita, J.; Uchiyama, M.; Raithby, P. R. Organometallics 2009, 28, 38-41.

12 Davies, R. P. Coord. Chem. Rev. 2011, 255, 1226-1251.

13 Selected bond lengths ( $\AA$ ) and angles ( $\left.{ }^{\circ}\right)$ : Li1-Cl1 2.344(6), Li1-Cl1A 2.328(6), Li1-N1 1.966(6), Li2-Cl1 2.371(6), Li2-N2 2.016(6), Cu1-N1 1.908(2), Cu1-N2 1.918(2), Cl1A-Li1-Cl1 98.7(2), Li1-Cl1-Li1A 81.3(2), Cl1-Li1-N1 128.5(3), Cl1-Li2-N2 128.2(3), N1-Cu1-N2 174.45(11).

14 (a) The ${ }^{1} \mathrm{H}$ and ${ }^{13} \mathrm{C}$ NMR data of $\mathbf{3 b}$ are analogous to those described: Kobayashi, K.; Suzuki, T.; Horiuchi, M.; Shiroyama, Y.; Konishi, H. Synthesis 2011, 2897-2906; (b) Compound 3c: orange oil; ${ }^{1} \mathrm{H}$ NMR $\left(300 \mathrm{MHz}, \mathrm{CDCl}_{3}\right) \delta 7.43(\mathrm{~m}, 4 \mathrm{H}), 7.57(\mathrm{dd}, 1 \mathrm{H}$, $J=7.6$ and $1.7 \mathrm{~Hz}), 7.88(\mathrm{dd}, 1 \mathrm{H}, J=7.6$ and $2.0 \mathrm{~Hz}), 8.52 \mathrm{ppm}(\mathrm{dd}, 1 \mathrm{H}, J=4.8$ and $2.0 \mathrm{~Hz}) ;{ }^{13} \mathrm{C} \mathrm{NMR}\left(75 \mathrm{MHz} \mathrm{CDCl}_{3}\right) \delta 122.7$ $(\mathrm{CH}), 127.3(\mathrm{CH}), 130.9(\mathrm{CH}), 131.2(\mathrm{CH}), 132.8(\mathrm{C}), 133.3(\mathrm{CH}), 134.9(\mathrm{C}), 137.1(\mathrm{C}), 139.5(\mathrm{CH}), 148.6(\mathrm{C}), 151.8(\mathrm{CH})$, $193.1 \mathrm{ppm}(\mathrm{C}=\mathrm{O})$; HRMS (ESI): $\mathrm{m} / z$ calcd for $\mathrm{C}_{12} \mathrm{H}_{7}{ }^{35} \mathrm{Cl}_{2} \mathrm{NNaO}\left[(\mathrm{M}+\mathrm{Na})^{+\bullet}\right]$ 273.9802, found 273.9805 .

15 Compound 4: yellow powder; $\mathrm{mp} 65{ }^{\circ} \mathrm{C}$; ${ }^{1} \mathrm{H}$ NMR $\left(300 \mathrm{MHz}, \mathrm{CDCl}_{3}\right) \delta 3.81(\mathrm{~s}, 3 \mathrm{H}), 7.01(\mathrm{dd}, 1 \mathrm{H}, J=7.5 \mathrm{and} 4.9 \mathrm{~Hz}), 7.37(\mathrm{~m}$, $3 \mathrm{H}), 7.46(\mathrm{~m}, 1 \mathrm{H}), 7.99(\mathrm{dd}, 1 \mathrm{H}, J=7.5$ and $2.0 \mathrm{~Hz}), 8.34 \mathrm{ppm}(\mathrm{dd}, 1 \mathrm{H}, J=4.9$ and $2.0 \mathrm{~Hz}) ;{ }^{13} \mathrm{C} \mathrm{NMR}\left(75 \mathrm{MHz}, \mathrm{CDCl}_{3}\right) \delta 53.9$ $\left(\mathrm{CH}_{3}\right), 117.1(\mathrm{CH}), 121.8(\mathrm{C}), 126.9(\mathrm{CH}), 129.7(\mathrm{CH}), 129.9(\mathrm{CH}), 131.5(\mathrm{CH}), 131.6(\mathrm{C}), 139.7(\mathrm{C}), 140.6(\mathrm{CH}), 151.3(\mathrm{CH})$, 162.2 (C), $193.7 \mathrm{ppm}(\mathrm{C}=\mathrm{O})$; HRMS (ESI): $\mathrm{m} / \mathrm{z}$ calcd for $\mathrm{C}_{13} \mathrm{H}_{11}{ }^{35} \mathrm{ClNO}_{2}\left[(\mathrm{M}+\mathrm{H})^{+\bullet}\right]$ and $\mathrm{C}_{13} \mathrm{H}_{10}{ }^{35} \mathrm{ClNNaO}_{2}\left[(\mathrm{M}+\mathrm{Na})^{+\bullet}\right] 248.0478$ and 270.0298 , found 248.0483 and 270.0298 , respectively.

16 The ${ }^{1} \mathrm{H}$ and ${ }^{13} \mathrm{C}$ NMR data of 5 are analogous to those described: Cahiez, G.; Luart, D.; Lecomte, F. Org. Lett. 2004, 6, 43954398.

17 Compound 6: yellow viscous oil; ${ }^{1} \mathrm{H}$ NMR $\left(300 \mathrm{MHz}, \mathrm{CDCl}_{3}\right) \delta 6.99(\mathrm{~d}, 1 \mathrm{H}, J=5.2 \mathrm{~Hz}), 7.41(\mathrm{~m}, 2 \mathrm{H}), 7.51(\mathrm{~m}, 2 \mathrm{H}), 7.77 \mathrm{ppm}$ $(\mathrm{m}, 2 \mathrm{H}) ;{ }^{13} \mathrm{C}$ NMR $\left(75 \mathrm{MHz}, \mathrm{CDCl}_{3}\right) \delta 128.4(2 \mathrm{CH}), 129.6(2 \mathrm{CH}), 130.1(\mathrm{CH}), 130.7(\mathrm{CH}), 133.0(\mathrm{CH}), 134.3(\mathrm{C}), 137.8(\mathrm{C})$, $187.8 \mathrm{ppm}(\mathrm{C}=\mathrm{O})$, one $\mathrm{C}$ not seen; HRMS (ESI): $\mathrm{m} / \mathrm{z}$ calcd for $\mathrm{C}_{11} \mathrm{H}_{8}{ }^{35} \mathrm{ClOS}\left[(\mathrm{M}+\mathrm{H})^{+\bullet}\right]$ and $\mathrm{C}_{11} \mathrm{H}_{7}{ }^{35} \mathrm{ClNaOS}\left[(\mathrm{M}+\mathrm{Na})^{+\bullet}\right] 222.9984$ and 244.9804 , found 222.9999 and 244.9803 , respectively.

18 Lockner, J. W.; Dixon, D. D.; Risgaard, R.; Baran, P. S. Org. Lett. 2011, 13, 5628-5631, and references cited therein

19 (a) Kloc, K.; Mlochowski, J.; Szulc, Z. J. Prakt. Chem. 1977, 319, 959-967; (b) Alvarado Urbina, G. Synth. Commun. 1979, 9 , 245-250; (c) Prostakov, N. S.; Soldatenkov, A. T.; Fedorov, V. O. Khim. Geterotsikl. Soedin. 1979, 1101-1103; (d) Soldatenkov, A. T.; Bagdadi, M. V.; Fedorov, V. O.; Prostakov, N. S. Khim. Geterotsikl. Soedin. 1986, 1212-1214; (e) Braven, J.; Hanson, R. W.; Smith, N. G. J. Heterocycl. Chem. 1995, 32, 1051-1055; (f) Rebstock, A.-S.; Mongin, F.; Trécourt, F.; Queguiner, G. Tetrahedron 2003, 59, 4973-4977; (g) Tilly, D.; Castanet, A.-S.; Mortier, J. Tetrahedron Lett. 2006, 47, 1121-1123.

20 Stauffer, K. J.; Williams, P. D.; Selnick, H. G.; Nantermet, P. G.; Newton, C. L.; Homnick, C. F.; Zrada, M. M.; Lewis, S. D.; Lucas, B. J.; Krueger, J. A.; Pietrak, B. L.; Lyle, E. A.; Singh, R.; Miller-Stein, C.; White, R. B.; Wong, B.; Wallace, A. A.; Sitko, G. R.; Cook, J. J.; Holahan, M. A.; Stranieri-Michener, M.; Leonard, Y. M.; Lynch, J. J., Jr.; McMasters, D. R.; Yan, Y. J. Med. Chem. 2005, 48, 2282-2293.

21 The ${ }^{1} \mathrm{H}$ and ${ }^{13} \mathrm{C}$ NMR data of 7 are analogous to those described: Liéby-Muller, F.; Allais, C.; Constantieux, T.; Rodriguez, J. Chem. Commun. 2008, 4207-4209.

22 Netherton, M. R.; Fu, G. C. Org. Lett. 2001, 3, 4295-4298.

23 General procedure: A degassed mixture of $\mathrm{K}_{2} \mathrm{CO}_{3}(0.28 \mathrm{~g}, 2.0 \mathrm{mmol}), \mathrm{Pd}(\mathrm{OAc})_{2}(11 \mathrm{mg}, 50 \mu \mathrm{mol}), \mathrm{Cy}_{3} \mathrm{P} \cdot \mathrm{HBF}_{4}(37 \mathrm{mg}, 0.1$ $\mathrm{mmol})$, the required ketone $(1.0 \mathrm{mmol})$, and in some cases $\mathrm{Pr}_{4} \mathrm{NCl}(0.44 \mathrm{~g}, 2 \mathrm{mmol})$, in $\mathrm{DMF}(4 \mathrm{~mL})$ was heated at $130{ }^{\circ} \mathrm{C}$ for 16 to $48 \mathrm{~h}$. After filtration over a celite pad, washing using $\mathrm{CH}_{2} \mathrm{Cl}_{2}(3 \times 10 \mathrm{~mL})$, and removal of the solvent under reduced pressure, the product was isolated after purification by flash chromatography on silica gel.

24 The ${ }^{1}$ H NMR data of $\mathbf{8}$ are analogous to those described: Prostakov, N. S.; Pleshakov, V. G.; Zain-ul-Abedin, M.; Kordova, I. R.; Zakharov, V. F.; Zvolinskii, V. P. Zh. Org. Khim. 1982, 18, 640-652.

25 Compound 9: yellow powder; mp $113{ }^{\circ} \mathrm{C} ;{ }^{1} \mathrm{H}$ NMR $\left(300 \mathrm{MHz}, \mathrm{CDCl}_{3}\right) \delta 3.96(\mathrm{~s}, 3 \mathrm{H}), 6.92(\mathrm{dd}, 1 \mathrm{H}, \mathrm{J}=8.3 \mathrm{and} 2.3 \mathrm{~Hz}), 7.24(\mathrm{dd}$, $1 \mathrm{H}, J=7.4$ and $5.1 \mathrm{~Hz}), 7.41(\mathrm{~d}, 1 \mathrm{H}, J=2.3 \mathrm{~Hz}), 7.7(\mathrm{~d}, 1 \mathrm{H}, J=8.3 \mathrm{~Hz}), 7.89(\mathrm{dd}, 1 \mathrm{H}, J=7.4 \mathrm{and} 1.6 \mathrm{~Hz}), 8.62 \mathrm{ppm}(\mathrm{dd}, 1 \mathrm{H}, J=$ 5.1 and $1.6 \mathrm{~Hz}) ;{ }^{13} \mathrm{C}$ NMR $\left(75 \mathrm{MHz}, \mathrm{CDCl}_{3}\right) \delta 56.1\left(\mathrm{CH}_{3}\right), 106.4(\mathrm{CH}), 116.7(\mathrm{CH}), 123.7(\mathrm{CH}), 126.4(\mathrm{CH}), 127.8(\mathrm{C}), 129.8$ (C), $131.2(\mathrm{CH}), 146.5(\mathrm{C}), 153.4(\mathrm{CH}), 164.2(\mathrm{C}), 166.1(\mathrm{C}), 190.3 \mathrm{ppm}(\mathrm{C}=\mathrm{O})$; HRMS (ESI): $\mathrm{m} / z$ calcd for $\mathrm{C}_{13} \mathrm{H}_{9} \mathrm{NNaO}_{2}$ $\left[(\mathrm{M}+\mathrm{Na})^{+\bullet}\right] 234.0531$, found 234.0534 .

26 Compound 10: yellow powder; $\mathrm{mp} 160{ }^{\circ} \mathrm{C} ;{ }^{1} \mathrm{H} \mathrm{NMR}\left(300 \mathrm{MHz}, \mathrm{CDCl}_{3}\right) \delta 4.13(\mathrm{~s}, 3 \mathrm{H}), 7.15(\mathrm{~d}, 1 \mathrm{H}, J=5.0 \mathrm{~Hz}), 7.44(\mathrm{td}, 1 \mathrm{H}, J=$ 7.2 and $1.6 \mathrm{~Hz}), 7.49-7.60(\mathrm{~m}, 2 \mathrm{H}), 7.71(\mathrm{ddd}, 1 \mathrm{H}, J=7.2,1.1$ and $0.8 \mathrm{~Hz}), 8.37(\mathrm{~d}, 1 \mathrm{H}, J=5.0 \mathrm{~Hz}) ;{ }^{13} \mathrm{C} \mathrm{NMR}\left(75 \mathrm{MHz}, \mathrm{CDCl}_{3}\right)$ $\delta 54.4\left(\mathrm{CH}_{3}\right), 109.8(\mathrm{CH}), 113.4(\mathrm{C}), 121.5(\mathrm{CH}), 124.3(\mathrm{CH}), 131.5(\mathrm{CH}), 134.1(\mathrm{C}), 134.2(\mathrm{CH}), 141.1(\mathrm{C}), 155.0(\mathrm{CH}), 156.4$ (C), $161.0(\mathrm{C}), 191.5(\mathrm{C}=\mathrm{O})$; HRMS (ESI): $\mathrm{m} / z$ calcd for $\mathrm{C}_{13} \mathrm{H}_{9} \mathrm{NNaO}_{2}\left[(\mathrm{M}+\mathrm{Na})^{+*}\right] 234.0531$, found 234.0532.

27 The ${ }^{1} \mathrm{H}$ and ${ }^{13} \mathrm{C}$ NMR data of $\mathbf{1 1}$ are analogous to those described: Dubrovskiy, A. V.; Larock, R. C. Org. Lett. 2010, 12, 31173119.

28 Campo, M. A.; Larock, R. C. J. Org. Chem. 2002, 67, 5616-5620.

$29 \mathrm{Mp} 106{ }^{\circ} \mathrm{C}$ (Arcus, C. L.; Barrett, G. C. J. Chem. Soc. 1960, 2098-2102: mp 107-109 ${ }^{\circ} \mathrm{C}$ ).

\section{Supplementary Material}

Supplementary data associated with this article and containing X-ray diffraction analysis and CIF files of 1 (CCDC 884940), 10 (CCDC 885440), and 13 (CCDC 885439), and NMR spectra of 3c, 4, 6, 9, 10 and 13 ) can be found in the online version, at http://dx.doi.org/10.1016/j.tetlet.xxxxxx. 